\title{
Morphological Characterization and Phenological Modeling of Jatropha platyphylla (Euphorbiaceae) Muell. Arg. Genotypes
}

\author{
Edith Salazar-Villa1, Martha Lidia Gutiérrez-Pérez², Federico Soto-Landeros ${ }^{3}$, \\ Karla Marina Báez-Parra4, María de la Paz Sosa-Segura5, \\ Miguel Angel Angulo-Escalante ${ }^{1^{*}}$
}

\author{
${ }^{1}$ Centro de Investigación en Alimentación y Desarrollo AC, Culiacán, México \\ ${ }^{2}$ Facultad de Agronomía, Universidad Autónoma de Sinaloa, Culiacán, México \\ ${ }^{3}$ Instituto Tecnológico Superior de Guasave, Guasave, México \\ ${ }^{4}$ Facultad de Ciencias Químico Biológicas, Universidad Autónoma de Sinaloa, Culiacán, México \\ ${ }^{5}$ Colegio de Bachilleres del Estado de Sinaloa, Culiacán, México \\ Email: *mangulo@ciad.mx
}

How to cite this paper: Salazar-Villa, E., Gutiérrez-Pérez, M.L., Soto-Landeros, F., Báez-Parra, K.M., Sosa-Segura, M.P. and Angulo-Escalante, M.A. (2022) Morphological Characterization and Phenological Modeling of Jatropha platyphylla (Euphorbiaceae) Muell. Arg. Genotypes. American Journal of Plant Sciences, 13, 23-35. https://doi.org/10.4236/ajps.2022.131002

Received: October 2, 2021

Accepted: January 10, 2022

Published: January 13, 2022

Copyright $\odot 2022$ by author(s) and Scientific Research Publishing Inc. This work is licensed under the Creative Commons Attribution International License (CC BY 4.0)

http://creativecommons.org/licenses/by/4.0/

(c) (i) Open Access

\begin{abstract}
Morphological characterization and phenological modeling were carried out on genotypes of Jatropha platyphylla collected from the states of Sinaloa and Durango, Mexico. The morphological characterization evidenced the existence of monoecious plants, finding individuals with male and female flowers in the same inflorescence. Fruit with four seeds was also found. The phenological study was divided into two phases and calculated in thermal requirement $\left({ }^{\circ} \mathrm{D}\right)$ : Vegetative [seedtime (0), germination (24), emergence (98), cotyledons (87), second (302) and fourth (524) true leaves, end of vegetative growth (302)] and reproductive [flowering (303), fructification (342), maturation (126), defoliation and senescence (450)]. The thermal constant (2558) was similar in all eight genotypes. The phenological stages and the accumulated degree days were adjusted with a third-degree polynomial (Stage $=$ $\left.-0.0041 x^{3}+0.7446 x^{2}-8.6808 x+6.2448\right)\left(\mathrm{R}^{2}=0.99 \%\right)$ stage. The development of phenological models facilitates the prediction of the flowering date for the selection of varieties with high oil and protein content.
\end{abstract}

\section{Keywords}

Degree-Days, Monoecious, Phenological Modeling, Plant Breeding, Varietal Selection 


\section{Introduction}

The genus Jatropha comprises approximately 170 to 175 known species, of which 45 are found in Mexico [1] with 77.7\% of endemism for ecosystems of low deciduous forest and xerophilous scrublands [2]. Jatropha platyphylla, a wild plant of the northwestern region of Mexico, is little known and with restricted geographical distribution to the deciduous lowland forest near the Pacific coast between Sinaloa and Michoacán [3]. It is a tree or shrub from 2 to $5 \mathrm{~m}$ tall with an almost smooth stem; broad leaves, almost orbicular, 25 to $35 \mathrm{~cm} \mathrm{[4]} \mathrm{with}$ broadly rounded lobes [5]. The fruit has three seeds of $12 \mathrm{~mm}$ long [6]. The flowers are white to pink; the plants bloom in May, June and July [7]. The plant is known as Bonete because of the shape of the fruit [5], as well as Sangregado for staining the garments that rub against its branches in blood color [8].

The fruit of J. platyphylla is used by the inhabitants of Tacuichamona Communities, Culiacán, Sinaloa, Mexico in traditional food preparation [9]. The fruit is consumed by animals, such as deer (Odocoileus virginianus) and wild boar (Sus scrota). The seed is food for birds, such as chachalaca (Ortalis vetula) and magpie (Cyanocorax mystacalis), among others [10]. The seed kernel has high oil content (60\%); the oil extraction residue cake contains $75 \%$ crude protein [9]. Sosa-Segura et al. [11] performed a physical and chemical characterization of three non-toxic oilseeds from the Jatropha genus; J. cinerea and J. curcas oils have fatty acid profile similar to those of sesame and canola oils, whereas that of J. platyphylla resembles those of soybean oil. Ambriz-Pérez et al. [12] studied extracts from J. platyphylla pulp, kernel, and leaves to know their effect on some pro-inflammatory mediators. Altogether, these results suggest that extracts have potential in treating inflammatory diseases, and their activity is mediated by flavonoids and lipophilic compounds. Soto-Landeros et al. [13] compared pollen morphology of four Jatropha species (J. curcas, J. cinerea, J. platyphylla, and J. vernicosa). The pollen grains among J. cinerea, J. platyphylla, and J. vernicosa showed great similarity in shape and size. The most distinctive differences were found in toxic and non-toxic J. curcas.

In Mexico and worldwide, the number of studies on Jatropha has increased because of the use of its seed oil to produce biodiesel. However, knowledge of taxonomy, distribution, and ethnobotany of these and related species is incomplete [14]. J. platyphylla is in domestication period and has not been fully characterized. Morphological studies of seeds represent important tools for the development of efficient agricultural practices [15] and knowledge of the phenology of a species, whether to develop as a new crop or cultivation already established, they have practical applications in planning and coordinating work to be carried out in the crop; thus resource optimization and an increase in productivity may be achieved [16]. Due to the potential of J. platyphylla and with the purpose of contributing to the development of a new crop, the objectives of this research aimed at studying the phenology of the plant, morphology of the root, stem, leaves, flowers, and fruit, a phenological development model based on am- 
bient temperature is proposed.

\section{Materials and Methods}

\subsection{Plant Material and Germination}

This research was conducted in April 2017 and involved eight wild populations of J. platyphylla growing under the tropical conditions of the states of Sinaloa and Durango in Northwestern Mexico (Table 1). Ripe fruit was collected to obtain the seeds; 100 seeds of each accession were washed with Axion ${ }^{\circledR}$ detergent (Colgate-Palmolive, NY, U.S.A.) for $10 \mathrm{~min}$ and subsequently treated with $30 \%$ commercial sodium hypochlorite (Cloralex ${ }^{\circledR}$, Nuevo León, MX) for 15 min and rinsed five times with distilled water; then, a pre-germination treatment was performed in distilled water at $60^{\circ} \mathrm{C}$ for one hour, and the part of the micropile was scarified. The treated seeds were placed on moistened paper for germination and incubated in a growth chamber at $25^{\circ} \mathrm{C} \pm 2^{\circ} \mathrm{C}$ in dark conditions. Once germination occurred, they were seeded in $250-\mathrm{mL}$ polypropylene cups, drilled on the base and with Sogemix ${ }^{\circledR}$ substrate (Quebec, CAN). Once the plants developed, they were placed in the greenhouse under controlled light and room temperature of $28^{\circ} \mathrm{C} \pm 7^{\circ} \mathrm{C}$ conditions; the seedling percentage obtained was assessed. In the pre-field stage developed in the greenhouse, complete plants were extracted from the pot; germination, emergence, appearance of true leaves and stem elongation were recorded. The plants were transplanted in open field at a distance of $2 \mathrm{~m}$ between plants and $3 \mathrm{~m}$ between rows; $60 \mathrm{~g}$ of triple 17 fertilizers and $1 \mathrm{~kg}$ of compost were applied to each plant as base fertilizer. Plants with homogeneous characteristics were selected, and stem length, number of leaves, and morphological evaluations of the different organs were recorded. For determination of stomatal index: Slides as prepared for stomatal index by using the formula,

$$
\text { Stomatal index }(\%)=(S / S+E) \times 100
$$

Table 1. Information on the sites where Jatropha platyphylla genotypes were collected and the average annual record of weather data.

\begin{tabular}{cccccccc}
\hline ID & Collection area & Latitude $\left({ }^{\circ} \mathrm{N}\right)$ & Longitude $\left({ }^{\circ} \mathrm{W}\right)$ & $\mathrm{Tmax}\left({ }^{\circ} \mathrm{C}\right)$ & Tmin $\left({ }^{\circ} \mathrm{C}\right)$ & $\begin{array}{c}\text { Relative Humidity } \\
(\%)\end{array}$ & $\begin{array}{c}\text { Precipitation } \\
(\mathrm{mm})\end{array}$ \\
\hline CP & Cofradia, Sinaloa & $24^{\circ} 51^{\prime} 44^{\prime \prime}$ & $107^{\circ} 11^{\prime} 00^{\prime \prime}$ & 33.4 & 16.0 & 78.8 & 881 \\
DM & Dimas, Sinaloa & $23^{\circ} 45^{\prime} 01^{\prime \prime}$ & $106^{\circ} 46^{\prime} 35^{\prime \prime}$ & 29.5 & 17.1 & 79.1 & 481 \\
LC & Chilla, Sinaloa & $24^{\circ} 23^{\prime} 27^{\prime \prime}$ & $107^{\circ} 06^{\prime} 17^{\prime \prime}$ & 31.2 & 18.2 & 74.5 & 790 \\
LH & Higuerita, Sinaloa & $24^{\circ} 45^{\prime} 37^{\prime \prime}$ & $107^{\circ} 08^{\prime} 39^{\prime \prime}$ & 35.2 & 22.0 & 80.1 & 881 \\
PP & Mocorito, Sinaloa & $25^{\circ} 04^{\prime} 05^{\prime \prime}$ & $107^{\circ} 43^{\prime} 15^{\prime \prime}$ & 33.6 & 16.7 & 65.0 & 684 \\
PR & Rosario, Sinaloa & $23^{\circ} 11^{\prime} 18^{\prime \prime}$ & $106^{\circ} 09^{\prime} 09^{\prime \prime}$ & 35.5 & 19.1 & 85.9 & 828 \\
QP & Quelite, Sinaloa & $23^{\circ} 31^{\prime} 51^{\prime \prime}$ & $106^{\circ} 30^{\prime} 10^{\prime \prime}$ & 32.2 & 18.4 & 81.3 & 640 \\
TP & Tamazula, Durango & $24^{\circ} 59^{\prime} 12^{\prime \prime}$ & $106^{\circ} 59^{\prime} 17^{\prime \prime}$ & 32.2 & 16.7 & 86.0 & 1031 \\
\hline
\end{tabular}


where, $S$ and $E$ are the number of stomata and epidermal cells respectively in microscopic view field. Like stomatal density, stomatal index (\%) can be calculated for both the surfaces of leaves [17]. Three-month plants were used and planted in an experimental plot located in the community La Campana, $\mathrm{Cu}-$ liacán, Sinaloa $\left(24^{\circ} 59^{\prime} 28^{\prime \prime} \mathrm{N}\right.$ and $\left.107^{\circ} 34^{\prime} 25^{\prime \prime} \mathrm{W}\right)$ at $97 \mathrm{~m}$ a.s.l.

\subsection{Collected Meteorological, Morphological, and Phenological Data}

Daily weather variables were recorded in an automated station (Adcon Telemetry ${ }^{\circledR}$, Vienna, AT) located in the study area. The calculation of degree-days $\left({ }^{\circ} \mathrm{D}\right)$ was performed using Equation (2).

${ }^{\circ} \mathrm{D}=($ Maximum temperature + Minimum temperature $) / 2-18.6$

where $18.6^{\circ} \mathrm{C}$ was the base temperature [2]. Weekly observations were made for one year, and the different phenophases were identified.

\subsection{Development of Scale and Phenological Model}

A third-degree polynomial was adjusted in a variable with phenological stages based on cumulative day-degrees. The phenological stages for Jatropha platyphylla were defined by a decimal scale, following the methodology proposed by the Federal Biological Research Centre for Agriculture and Forestry [18].

\section{Results and Discussion}

\subsection{Morphological Description of Jatropha platyphylla}

Seed germination began on the third day after sowing and continued upon the fifth day at an average temperature of $21^{\circ} \mathrm{C} .80 \%$ germination was observed in the 8 genotypes. The shelled seed opened and the radicle showed a constant and vertical growth that constitutes the taproot and four lateral roots with abundant ramifications (Figure 1(a)).

The structural characteristics of roots may therefore provide soil resistance to water and wind erosion in some sites [19] [20]. J. platyphylla presented epigeal germination, where cotyledons emerged above the ground, as for most species of this genus [21]. The cotyledons are wrapped by the thick endosperm and reddish-white coloration. The verticality of the hypocotyl and the emergence of the second leaf true made evident the beginning of vegetative development, where you can see the deployment of the leaves cotyledonary, foliage development and fall of cotyledons.

The stem bark is whitish gray and was observed straight without ramifications during the first year (Figure 1(b)). The leaves are distributed alternately (spiral) along the stem and have 5 ribs principal. Each leaf is 33 to $42 \mathrm{~cm}$ long and 35 to $44 \mathrm{~cm}$ wide. The leaf is peltated because the petiole is inserted almost to the center of the leaf, the petiole is 20 to $38 \mathrm{~cm}$ long and has a basal diameter of 7 to 8 $\mathrm{mm}$ (Figure 1(c)). Dehgan [4], describes the leaves of J. platyphylla as thickened, 

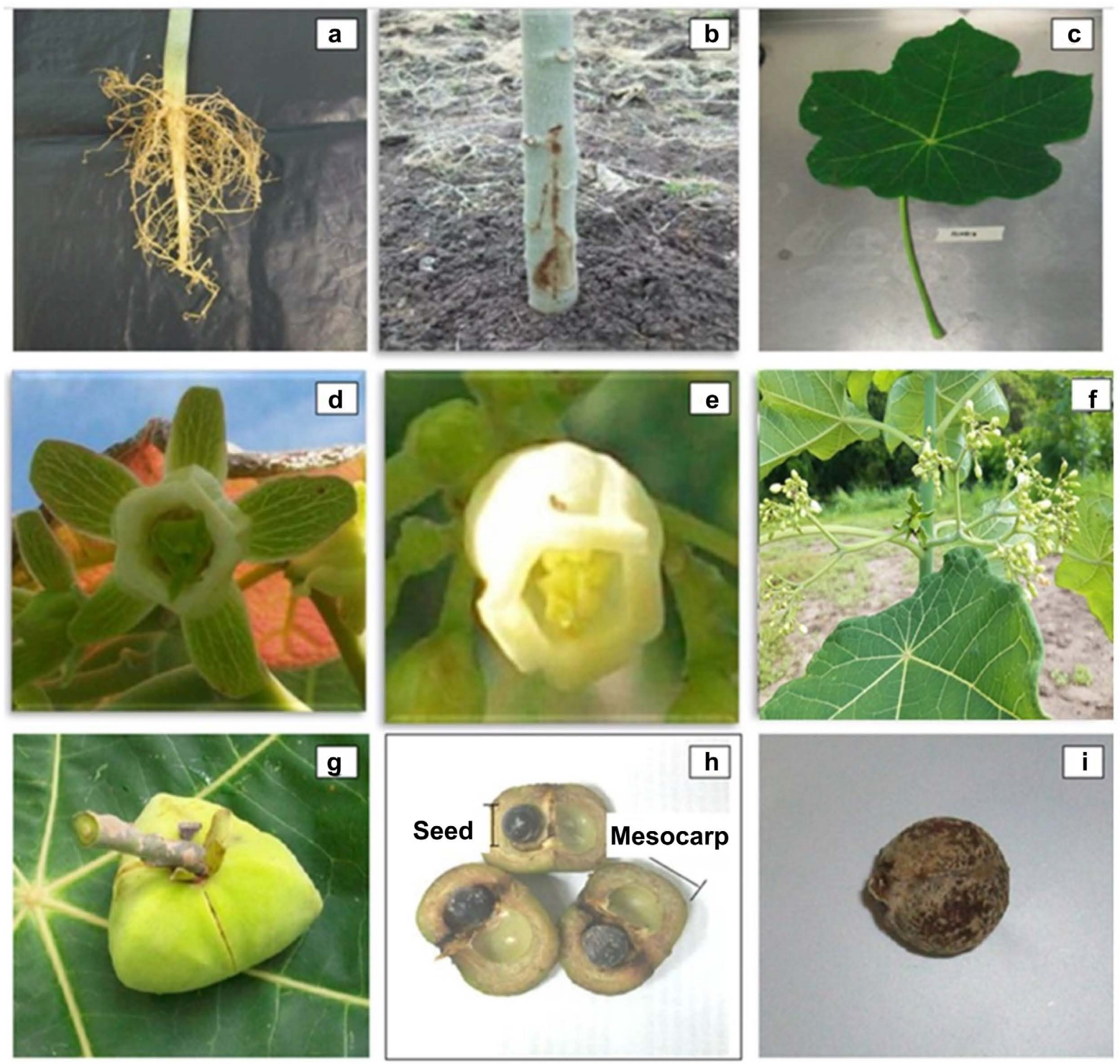

Figure 1. Jatropha platyphylla of La Campana, Sinaloa, Mexico; (a) Root, (b) Stem, (c) Leaf, (d) Female flower, (e) Male flower, (f) Monoecious flowering, (g) Mature fruit, (h) Dissected fruit, (i) Seed.

25 to $35 \mathrm{~cm}$, peltated, it should be noted that the description does not mention the size of the petioles, it only describes them as long petioles.

The morphological and anatomical variation of the leaves of the genus Jatropha facilitate taxonomic classification. The leaf of the species of the genus varies even those with 35 to $40 \mathrm{~cm}$ long [22]. The leaf blades are armored with 5 lobes. They presented stomata only in abaxial epidermis (hypostomatic) and stomata are of paracytic type. (Figure 2), unlike Jatropha curcas that presents stomata on both surfaces [23]. The stomatic index was found in a range from 23.08 to 35.14 in contrast $J$. curcas attain average of 7.076 in adaxial and 30.959 in abaxial surface [24]. Stomata are a promising trait as they reveal information on habitat preferences and there with ecological characteristics of species such as light conditions, as water use [25]. 


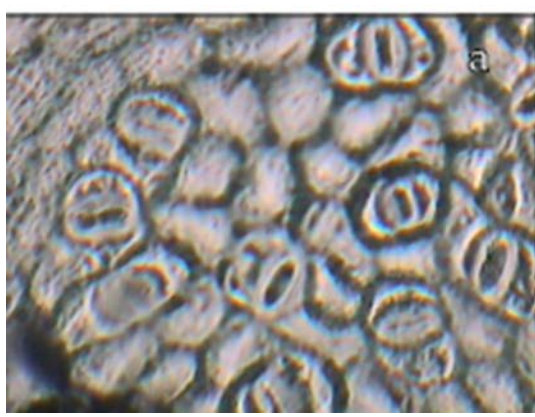

(a)

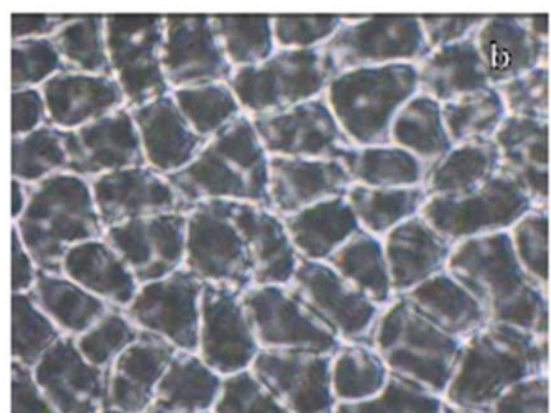

(b)

Figure 2. View of the abaxial epidermis (a) and adaxial (b) of the leaf lamina of Jatropha platyphylla obtained from an experimental lot of La Campana, Sinaloa.

The pistillate and staminate flowers of J. platyphylla are white, The pedicel of the pistillate flower ranged in a range of 10.43 to $16.69 \mathrm{~mm}$ long (Figure 1(d)) and 4.28 to $5.49 \mathrm{~mm}$ for the staminate flower (Figure 1(e)), both presented 5 petals $5.14 \mathrm{~mm}$ wide on average and $8.29 \mathrm{~mm}$ long; sepals 12 to $15 \mathrm{~mm}$ long by 5 - $6 \mathrm{~mm}$ wide. Dehgan and Schutzman [26] describe the sex of the J. platyphylla plant as dioecious, however; monoecious individuals were identified that presented male and female flowers in the same inflorescence only in PP (Mocorito, Sinaloa) genotypes (Figure 1(f)).

Fruits are trilocular and tricarpelar drupe fleshy capsules that are initially green in colour, but turn yellow and then yellowish-brown and dehiscent as it matures (Figure $1(\mathrm{~g})$ ). In the genotypes, TP (Tamazula, Durango) and LH (La Higuerita, Sinaloa), the development of fruits with four carpels and four seeds was observed (Figure $1(\mathrm{~h})$ ). Its dimensions are $4.5 \mathrm{~cm}$ wide and $4.5 \mathrm{~cm}$ high, with a weight of 31 to 45 grams. The weight of the mature fruit of J. platyphylla corresponds to $15 \%$ of seeds and $75 \%$ of mesocarp and epicarp. Each fruit presented a seed in each locule, round brown in shape, with thick endocarp, weighing 1.01 to 2.06 grams, with an average weight of $1.79 \pm 0.22$, diameter of 13.03 to $16.02 \mathrm{~mm}(14.63 \pm 0.60)$. These results agree with Makkar et al. [9], who describe the almost circular seed with a diameter of $15.54 \pm 1.01 \mathrm{~mm}$. The average weight of $1.80 \pm 0.15$ for the whole seed, $0.92 \pm 0.01$ for the shell and $0.85 \pm 0.13$ for the kernel. Shells represent more than $50 \%$ of the total weight of the seed. On the other hand, Standley [6] reports $12 \mathrm{~mm}$ seeds (Figure 1(i)). The difference in diameter may be due to the climatic and edaphological conditions in which the plants were, or to the genotypes under study [27] [28].

\subsection{Phenology of Jatropha platyphylla}

The development of Jatropha platyphylla was observed in two stages: Vegetative; which included 7 phenological events (sowing, germination, emergency, cotyledonary stage, 2nd leaf, 4th leaf and term of vegetative growth), and Reproductive (flowering, fruiting, physiological maturity, defoliation and senescence) (Figure 3). Table 2 shows the relationship between the physiological time $\left({ }^{\circ} \mathrm{D}\right)$ and the chronological time obtained, and the phenological responses recorded during 


\section{Vegetative stage}

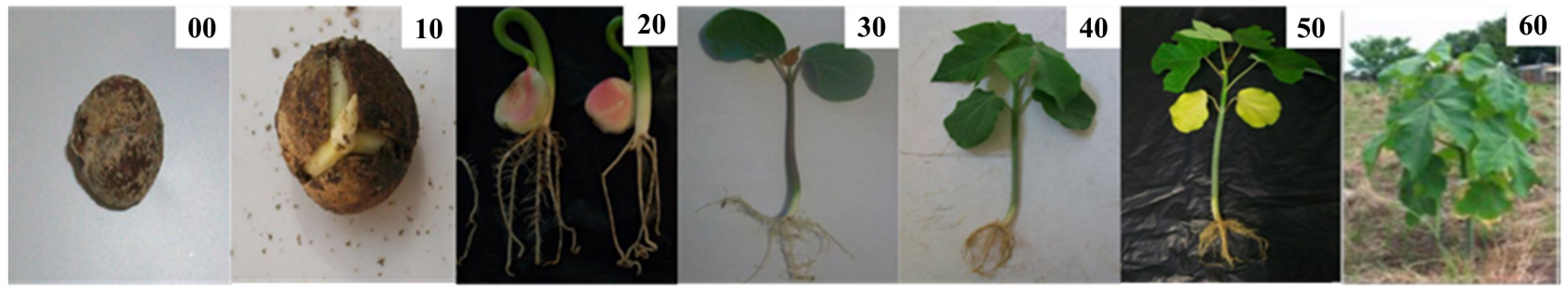

Reproductive stage

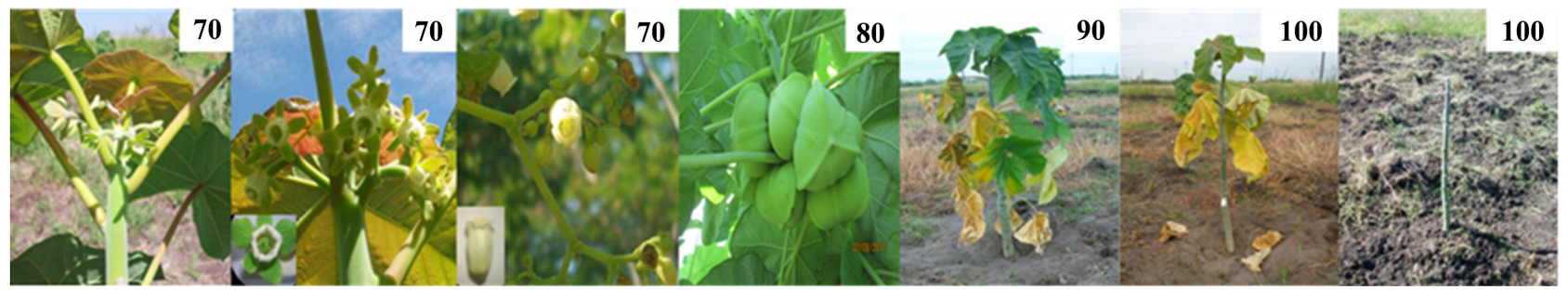

Figure 3. Coding and phenological stages of Jatropha platyphylla (monoecious and dioecious) (BBCH, 2001) [18].

Table 2. Thermal requirement [accumulated degree-days $\left.\left({ }^{\circ} \mathrm{D}\right)\right]$ and chronological time for the phenological stage of Jatropha platyphylla.

\begin{tabular}{cccccc}
\hline \multirow{2}{*}{ BBCH Scale } & Phenological stage & \multicolumn{2}{c}{ Degree days $\left({ }^{\circ} \mathrm{D}\right)$} & \multicolumn{2}{c}{ Average date } \\
\cline { 3 - 6 } & & Per stage & Accumulated & Per stage & Accumulated \\
\hline 00 & Sowing & 0 & 0 & 0 & 0 \\
10 & Germination & 24 & 24 & 3 & 3 \\
20 & Seedling emergence & 98 & 122 & 14 & 17 \\
30 & Cotyledon stage & 87 & 209 & 8 & 25 \\
40 & 2nd true leaf & 302 & 511 & 27 & 52 \\
50 & 4th true leaf & 524 & 1035 & 42 & 94 \\
60 & Vegetative cycle & 302 & 1337 & 25 & 119 \\
70 & Flowering & 303 & 1640 & 30 & 149 \\
80 & Fruiting & 342 & 1982 & 41 & 190 \\
90 & Maturing & 126 & 2108 & 63 & 253 \\
100 & Senescence & 450 & 2558 & 70 & 323 \\
\hline
\end{tabular}

the study season. The development of the plant was evident after certain phenomena, such as the appearance of the air system, manifested by the emergence of the curved hypocotyl that occurred between the fifth and fourteenth day after planting with a requirement of $98^{\circ} \mathrm{D}$. The plant was required to accumulate a total of $2558\left({ }^{\circ} \mathrm{D}\right)$ and 323 calendar days, to complete its biological cycle; where, $1337^{\circ} \mathrm{D}$ were for the vegetative cycle and 115 calendar days, while $1221^{\circ} \mathrm{D}$ and 208 calendar days were required for the reproductive cycle. It was determined that a cumulative thermal requirement of $1035^{\circ} \mathrm{D}$ is necessary for the appear- 
ance of the first four true leaves. Likewise, $303^{\circ} \mathrm{D}$ were required for flowering. The thermal requirements for the formation of the first fruit cluster were $1982^{\circ} \mathrm{D}$ accumulated. Moraes et al. [29] evaluated Jatropha curcas irrigated and non irrigated systems, they found for fruit development was required $3271^{\circ} \mathrm{D}$ and $2245^{\circ} \mathrm{D}$, respectively. In more favorable environmental conditions, the plants require more degree days for flowering, whereas a higher percentage of energy is expended on growth and dry matter accumulation. Potentially, there is a physiological binomial growth development, which is sometimes balanced. However, increased investment in one event deters the progress of another and vice versa. The same data distribution is not recognized for the counting of days, because this variable is less appropriate for the estimation of plant development [30].

The growth of the plant expressed in height showed to be continuous. J. platyphylla grew rapidly, in 3 months it acquired a height of $30 \mathrm{~cm}$ on average, similar to that reported for 12, wherein 3 months it can reach between 30 and $40 \mathrm{~cm}$ high [31]. The plants reached an average height of $74 \mathrm{~cm}$ until the beginning of fruiting, where a stalk in the growth of the stem was observed, which remained constant until reaching a maximum growth of $80 \mathrm{~cm}$ during the cycle April 2017 to March 2018. Jatropha plants take 5 to 7 weeks to reach the appropriate transplant height in the field [31]. The phenology of fruit species such as J. platyphylla depends largely on the environmental conditions of a particular year, which is why some interannual variability can be expected in the occurrence of phenological events [32]. Reproductive development started after 4 months of sowing, in the month of September during the rainy season. However, in tropical and humid regions it occurs almost all year [31]. The continuous flowering of the place to the production of fruits for 4 months per year, so it must be harvested 3 times during this period [33]. In November, the leaf fall began and in January, completely bare plants were observed, the plant being in a state of winter rest or dormancy.

The data analysis indicates that the highest development rate occurred at an average temperature of $29^{\circ} \mathrm{C}$, where the growth increase was $18 \mathrm{~cm}$. Optimal climate conditions reported for $J$. platyphylla include temperatures of $29^{\circ} \mathrm{C}$ $34.0^{\circ} \mathrm{C}$ and annual precipitation of $800-1500 \mathrm{~mm}$ [22]. In January 2018, the average temperature was $18^{\circ} \mathrm{C}$ and low plant growth $(0.6 \mathrm{~cm})$ was obtained. This growth habit has been described in J. curcas at range of $18^{\circ} \mathrm{C}$ [33] $-18.6^{\circ} \mathrm{C}$ [34]. The value of lower basal temperatures for the development of Jatropha was estimated at $7.2^{\circ} \mathrm{C}$ in total cycle stage [28]. The results show that J. platyphylla responds better to climates with high average temperatures (greater than $19^{\circ} \mathrm{C}$ ) than to cold temperatures, where its growth decreases (Figure 4).

\subsection{Jatropha platyphylla Phenology Model}

The estimated model for J. platyphylla in cumulative degree-days $\left({ }^{\circ} \mathrm{DA}\right)$ was Equation (3).

$$
\text { Stage }=-0.0041 x^{3}+0.7446 x^{2}-8.6808 x+6.2448
$$




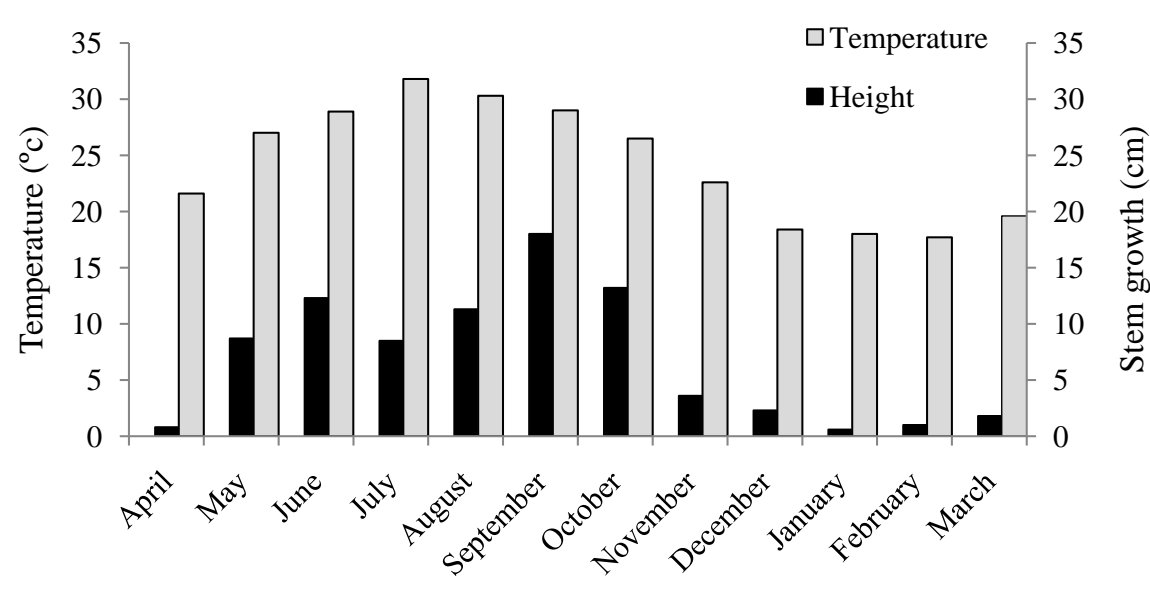

Figure 4. Influence of temperature on the growth of the Jatropha platyphylla plant (2017-2018) obtained from the experimental lot of La Campana, Culiacán, Mexico.

High correlation was observed in model $\left(\mathrm{R}^{2}=0.9927\right)$. Cesaraccio et al. [35] mentioned if a model is accurate, the regression slope should be near unity and the intercept near zero. Using the fitted model it was possible to determine phenological stage record from the date of sowing the maximum and minimum temperatures, and calculate the degrees days accumulated ( $\left.{ }^{\circ} \mathrm{DA}\right)$ (Figure 5). The calculated models allow to predict of the phenological stages of the plant, for this it is necessary to record from the date of sowing the maximum and minimum temperatures, and calculate the degrees days accumulated ( $\left.{ }^{\circ} \mathrm{DA}\right)$. Phenological models are tools aimed at knowing and predicting the development of plants such as flowering and development of seeds [30], and an instrument for observing forest phenology at climate change [36]. The application of these models includes the estimation of the harvest times of some crops; they also allow the implementation of agronomic practices oriented to increase or decrease the development of the crop, with the management of the temperature through ventilation in a production greenhouse of plants. In the same way, it can allow the planning of other management practices with great influence on growth such as fertilization, planting time, irrigation, pest management and diseases [37]. Crop and pest models can be used concurrently to forecast watering points for the crop based on the state of phenological development and thermal requirement [38] [39]. Degree-day calculations are essentially statistical features needed for calculation. In the context of nonlinear development summation, their precise values are less critical, and they are used mostly as convenient cut points for calculation. The actual existence of such thresholds is questionable, because they are very difficult to measure owing to excessive mortality when organisms are kept at those temperatures for long periods [40]. The non-linear relationship between phenology and temperature can explain the different responses to warm climates in woody and herbaceous species [41]. Observational studies at the local scale, together with local meteorological observations, can generate suggestions for possible environmental drivers of phenology [42]. 


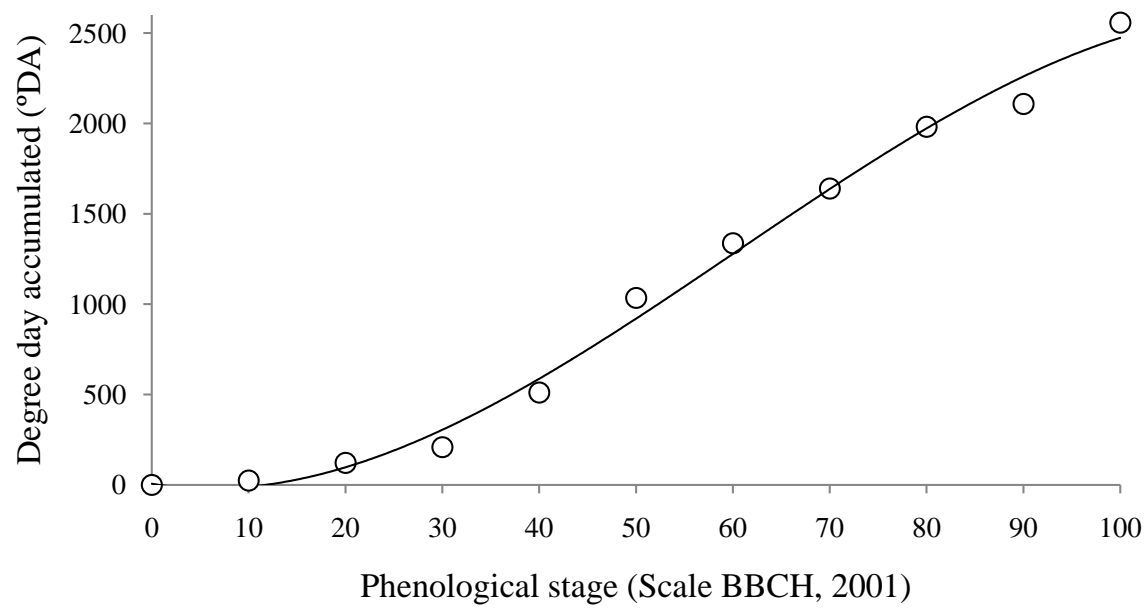

Figure 5. Estimated model for the phenological stages of Jatropha platyphylla.

\section{Conclusion}

Increasing temperatures have a significant effect on crop phenology. The results suggested that the model is a simple and accurate method to approximate the daily temperature curve from maximum and minimum daily temperatures and calculate growing degree-day values. The estimated model for J. platyphylla in cumulative degree-days $\left({ }^{\circ} \mathrm{DA}\right)$ provided excellent estimates of the number of days between phenological stages. The good predictive capability of the algorithms tested suggested that they were adequate for estimating effects on J. platyphylla phenology. Phenology is also one of the most important phenotypes considered in varietal selection in plant breeding.

\section{Acknowledgements}

The authors thank Veronica Perez, Briceida Perez, Eduardo Sanchez, Werner Rubio and Jorge Manjarrez for technical assistance. Special thanks were to Diana Fischer for English editing and to Lluvia de Abril Alexandra Soriano Melgar for proofreading the article.

\section{Conflicts of Interest}

The authors declare no conflicts of interest regarding the publication of this paper.

\section{References}

[1] Rodríguez-Acosta, M., Vega-Flores, K. and Gante-Cabrera, V. (2009) Distribución del género Jatropha L. (Euphorbiaceae) en el estado de Puebla, México. Instituto Politénico Nacional. México. Polibotánica, 28, 37-48.

[2] Martínez, M., Jiménez, J. and Cruz, R. (2002) Los géneros de la familia Euphorbiaceae en México. Anales del Instituto de Biología. Universidad Nacional Autónoma de México. Serie Botánica, 73, 155-281.

[3] Salazar-Villa, E., Alcaraz-Meléndez, L., León-Félix, J., Heredia, J., Soto-Landeros, F. and Angulo-Escalante, M. (2020) Morphological Variability and Oil Content of Ja- 
tropha platyphylla Müll. Arg. Germplasm as Determined Using Multivariate Analysis. Scientia Horticulturae, 261, Article ID: 108968.

https://doi.org/10.1016/j.scienta.2019.108968

[4] Dehgan, B. and Linder, G. (1979) Morphology and Infrageneric Relationships of the Genus Jatropha (Euphorbiaceae). University of California Press, Berkeley.

[5] Martínez, M. (1979) Catálogo de nombres vulgares y científicos de plantas mexicanas. FCE México, 1220 p.

[6] Standley, P.C. (1967) Trees and Shrubs of Mexico. United States National Herbarium, Washington DC, 635-639.

[7] Noguera, F., Vega, A. and García, J. (2002) Historia natural de Chamela. Universidad Nacional Autónoma de México, México.

[8] Schroeder, N. (2006) El ejido como institución de acción colectiva en el manejo de los ecosistemas de la región de Chamela-Cuixmala, Jalisco. Instituto de Ecología, A.C. Xalapa, Veracruz, México.

[9] Makkar, H.P.S., Kumar, V. and Oyeleye, O. (2011) Jatropha platyphylla, a New Non-Toxic Jatropha Species: Physical Properties and Chemical Constituents Including Toxic and Antinutritional Factors of Seeds. Food Chemistry, 125, 63-71. https://doi.org/10.1016/j.foodchem.2010.08.037

[10] Flores, E. (1999) Flora Silvestre de Sinaloa, su fenología y relación ecológica. Universidad de Sinaloa, Culiacán, Sinaloa.

[11] Sosa-Segura, M.P., Oomah, B. and Drover, J. (2014) Physical and Chemical Characterization of Three Non-Toxic Oilseeds from the Jatropha Genus. Journal of Food and Nutrition Research, 2, 56-61.

[12] Ambriz-Pérez, D.L., Bang, W.Y. and Nair, V. (2016) Protective Role of Flavonoids and Lipophilic Compounds from Jatropha platyphylla on the Suppression of Lipopolysaccharide (LPS)-Induced Inflammation in Macrophage Cells. Journal of Agricultural and Food Chemistry, 64, 1899-1909.

https://doi.org/10.1021/acs.jafc.5b05534

[13] Soto-Landeros, F., Alcaraz-Meléndez, L. and Angulo-Escalante, MA. (2016) Pollen morphology of Four Species of Jatropha (Euphorbiaceae), Including Toxic Varieties, in Northwestern Mexico. Revista de Biología Tropical, 65, 799-806. https://doi.org/10.15517/rbt.v65i2.24538

[14] Fresnedo-Ramírez, J. and Orozco-Ramírez, Q. (2013) Diversity and Distribution of Genus Jatropha in Mexico. Genetic Resources and Crop Evolution, 60, 1087-1104.

https://doi.org/10.1007/s10722-012-9906-7

[15] Christo, L.F., Colodetti, T.V., Rodrigues, W.N., Martins, L.D., do Amaral, J.F.T., Laviola, B.G. and Tomaz, M.A. (2014) Genetic Variability among Genotypes of Physic Nut Regarding Seed Biometry. American Journal of Plant Sciences, 5, 1416-1422. https://doi.org/10.4236/ajps.2014.510156

[16] Rivera, C. and Devoto, L. (2003) Desarrollo fenológico de 20 clones de Vitis vinífera. Bloque Fundación Vivero AgroUC, Pirque. Pontificia Universidad Católica de Chile.

[17] Paul, V., Sharma, L., Pandey, R. and Meena, R.C. (2017) Measurements of Stomatal Density and Stomatal Index on Leaf/Plant Surfaces. Manual of ICAR Sponsored Training Programme for Technical Staff of ICAR Institutes on "Physiological Techniques to Analyze the Impact of Climate Change on Crop Plants”, Vol. 27.

[18] BBCH (2001) Estadios de las Plantas Mono y Dicotiledóneas. Monografía. Centro Federal de Investigaciones Biológicas para Agricultura y Silvicultura Alemania. 
[19] Solomon, E., Berg, L and Martín, D. (2001) Biología. Editorial McGraw-Hill, Quinta Edición, México.

[20] Valdés-Rodríguez, O.A., Sánchez-Sánchez, O., Pérez-Vázquez, A., et al. (2013) Jatropha curcas L. Root Structure and Growth in Diverse Soils. The Scientific World Journal, 2013, Article ID: 827295. https://doi.org/10.1155/2013/827295

[21] Brasileiro, B.G., Dias, D.C.F.D.S., Bhering, M.C. and Dias, L.A.D.S. (2012) Floral Biology and Characterization of Seed Germination in Physic Nut (Jatropha curcas L.). Revista Brasileira de Sementes, 34, 556-560. https://doi.org/10.1590/S0101-31222012000400005

[22] Téllez, L.C., Ramírez, E.B., Colmenero, A.Z., Rivera Lorca, J.A., Vázquez, A.P., Sánchez Sánchez, O.M., et al. (2015) Diagnóstico y plan estratégico de Jatropha spp. en México. SNIC, SINAREFI, México, 116 p.

[23] Dehgan, B. (1980) Application of Epidermal Morphology to Taxonomic Delimitations in the Genus Jatropha L. (Euphorbiaceae). Botanical Journal of the Linnean Society, 80, 257-278. https://doi.org/10.1111/j.1095-8339.1980.tb01989.x

[24] Misra, M. and Misra, A.N. (2010) Jatropha: The Biodiesel Plant Biology, Tissue Culture and Genetic Transformation-A Review. International Journal of Pure and Applied Sciences, 1, 11-24.

[25] Bucher, S.F., Auerswald, K., Grün-Wenzel, C., Higgins, S.I., Garcia Jorge, J. and Römermann, C. (2017) Stomatal Traits Relate to Habitat Preferences of Herbaceous Species in a Temperate Climate. Flora, 229, 107-115. https://doi.org/10.1016/j.flora.2017.02.011

[26] Dehgan, B. and Schutzman, B. (1994) Contributions toward a Monograph of Neotropical Jatropha: Phenetic and Phylogenetic Analyses. Annals of the Missouri Botanical Garden, 81, 349-367. https://doi.org/10.2307/2992102

[27] Martin, M. and Montes, J. (2015) Quantitative Genetic Parameters of Agronomic and Quality Traits in a Global Germplasm Collection Reveal Excellent Breeding Perspectives for Jatropha curcas L. GCB Bioenergy, 7, 1335-1343. https://doi.org/10.1111/gcbb.12227

[28] Wen, Y., Tanga, M., Suna, D., Zhu, H., Wei, J., Chen, F., et al. (2012) Influence of Climatic Factors and Soil Types on Seed Weight and Oil Content of Jatropha curcas in Guangxi, China. Procedia Environmental Sciences, 12, 439-444. https://doi.org/10.1016/j.proenv.2012.01.301

[29] Moraes, D.H.M., Casaroli, D., Evangelista, A.W.P., Alves Júnior, J., Battisti, R. and Mesquita, M. (2019) Determination of Basal Temperature and Its Relationship with Jatropha Crop in Irrigated and Non-Irrigated System. Journal of Agricultural Science, 11, 465-476. https://doi.org/10.5539/jas.v11n2p465

[30] Machado, E.C.R., Lima, R.O.S., Silva, A.P.P., Marques, B.S., Gonçalves, M.F. and Carvalho, S.J.P. (2014) Crescimento e desenvolvimento inicial do capim-carrapicho com base em unidades térmicas. Planta Daninha, 32, 335-343. https://doi.org/10.1590/S0100-83582014000200011

[31] Toral, O.C., Iglesias, J.M., Montes de Oca, S., et al. (2008) Jatropha curcas L., una especie arbórea con potencial energético en Cuba. Pastos y Forrajes, 31, 191-207.

[32] Sánchez, D., Arends, E. and Rendón, J. (2002) Aspectos fenológicos de seis especies frutales arbóreas, usadas por la etnia Piaroa en la Reserva Forestal Sipapo, estado Amazonas, Venezuela. Pittiera, 31, 17-24.

[33] Carels, N. (2009) Jatropha curcas: A Review. Advances in Botanical Research, 50, 39-86. https://doi.org/10.1016/S0065-2296(08)00802-1 
[34] Falasca, S. and Ulberich, A. (2008) Las especies del género Jatropha para producir biodiesel en Argentina. Revista virtual REDESMA Biocombustibles, 2, 1-19.

[35] Cesaraccio, C., Spano, D., Duce, P. and Snyder, R.L. (2001) An Improved Model for Determining Degree-Day Values from Daily Temperature Data. International Journal of Biometeorology, 45, 161-169. https://doi.org/10.1007/s004840100104

[36] Laskin, D.N., McDermid, G.J., Nielsen, S.E., Marshall, S.J., Roberts, D.R. and Montaghi, A. (2019) Advances in Phenology Are Conserved across Scale in Present and Future Climates. Nature Climate Change, 9, 419-425.

https://doi.org/10.1038/s41558-019-0454-4 https://www.nature.com/articles/-s41558-019-0454-4

[37] López, M.A.M., Chaves, C.B. and Flórez, R.V.J. (2011) Modelos de cultivos y modelos fenológicos. In: Flórez, R.V.J., Eds., Sustratos, manejo del clima, automatización y control en sistemas de cultivo sin suelo, Editorial Universidad Nacional de Colombia, Bogotá, 153-177.

[38] Valdez-Torres, J.B., Soto-Landeros, F., Osuna-Enciso, T., et al. (2012) Phenological Prediction models For White Corn (Zea mays L.) and Fall Armyworm (Spodoptera frugiperda J. E. Smith). Agrociencia, 46, 399-410.

[39] Saint-André, N.F., Juan, V.F., Saint André, H.M. and Chantre, G.R. (2018). Demographic and Phenological Studies on David's Spurge (Euphorbia davidii) in the Central Area of Buenos Aires Province, Argentina. Planta Daninha, 36, Article ID: e18174369. https://doi.org/10.1590/s0100-83582018360100088

[40] Chuine, I. and Régnière, J. (2017) Process-Based Models of Phenology for Plants and Animals. Annual Review of Ecology, Evolution, and Systematics, 48, 159-182. https://doi.org/10.1146/annurev-ecolsys-110316-022706

[41] Jochner, S., Sparks, T.H. and Laube, J. (2016) Can We Detect a Nonlinear Response to Temperature in European Plant Phenology? International Journal of Biometeorology, 60, 1551-1561. https://doi.org/10.1007/s00484-016-1146-7

[42] McDonough MacKenzie, C., Gallinat, A.S. and Zipf, L. (2020) Low-Cost Observations and Experiments Return a High Value in Plant Phenology Research. Applications in Plant Sciences, 8, Article ID: e11338. https://doi.org/10.1002/aps3.11338 